\title{
David Niv - 1950 to 2007
}

\author{
Michael Gofeld MD ${ }^{1}$, David Shulman MD²
}

\begin{abstract}
"While from time to time people die as a result of pain, to our sorrow many more experience pain at the time of death, and even more suffer from pain and live in its shadow."
\end{abstract}

$\mathrm{T}_{\mathrm{of}}^{\mathrm{h}}$

hese are the words of David Niv,

Professor of Medicine at the University of Tel Aviv, Israel, who died tragically on February 6, 2007. He was esteemed by his colleagues and revered by his patients as a dedicated clinician and researcher in the field of chronic pain. He was among the first in Israel to promote the concept that chronic pain is a disease in its own right, worthy of serious study and treatment, and not just a symptom.

David received his medical education in Bologna, Italy and graduated in 1977. He specialized in anesthesiology and intensive care. Thereafter, he joined the unit for treatment of chronic pain at the Ichilov Hospital, Tel Aviv which was the first such unit to be established in Israel. Earlier this year, the entire Israeli pain community celebrated the 40th anniversary of the unit, which currently is named the Pain Medicine Center in the Tel Aviv Sourasky Medical Center. David Niv became a well respected and energetic researcher in chronic pain, and over his 27-year career he published more than 120 scientific articles. His research interests included neuraxial opioids, obstetrical and preemptive analgesia and DNA markers of familial disease. He served as the President of the Israeli Pain Association (IASP chapter) for many years. He was elected as the President of the European Federation of IASP (EFIC) in 1999 and served with distinction until 2002. In this capacity he launched the historic initiative "Europe against pain”. EFIC lobbied the European Parliament to declare chronic pain as a disease and to endorse educational activity, research and financing of European pain medicine. He founded the World Institute of Pain in 1995. At the time of his death he had just started his last project, the International Forum of Pain Medicine.

One of the many physicians who studied under Professor Niv said of him, "He developed remarkable ideas and opened before us the world of chronic pain management as an integral part of medicine."

Professor Niv was known for his concern and care for his patients. He often worked long hours in his clinic and saw patients up to the late evening hours. It was this dedication that resulted in a tragic outcome. As he was returning from his clinic at 1:30 am on February 6, he was murdered while in his car. His death at age 57 is a tragic loss for his family, friends, colleagues and patients, and a loss for the world pain community.

${ }^{1}$ Pain Management Program, Department of Anaesthesia, Sunnybrook Campus, University of Toronto, North York; ${ }^{2}$ Rouge Valley Health System, Ajax and Pickering Site, Ajax, Ontario 


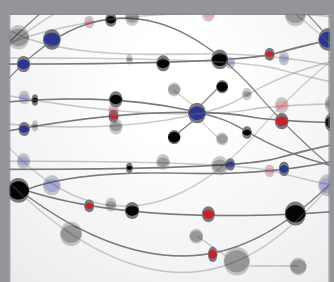

The Scientific World Journal
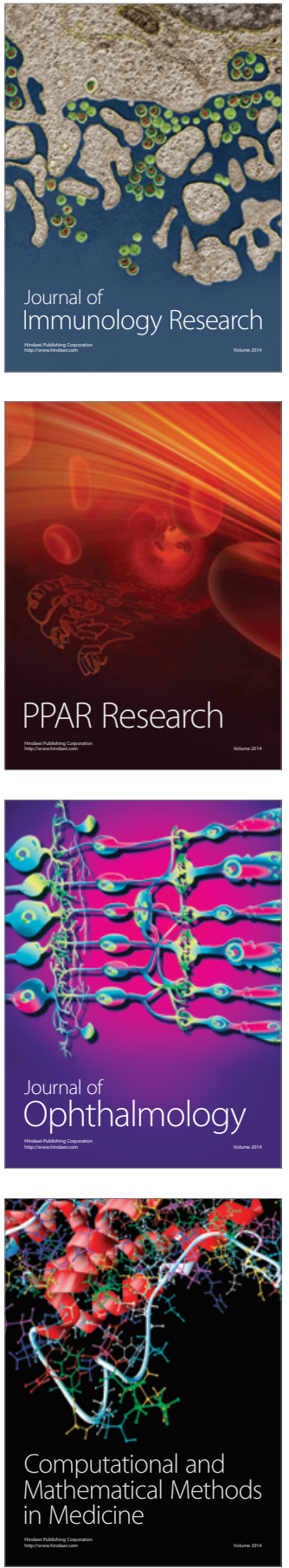

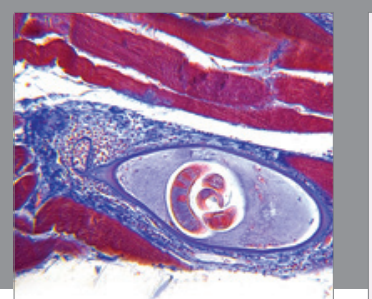

Gastroenterology Research and Practice

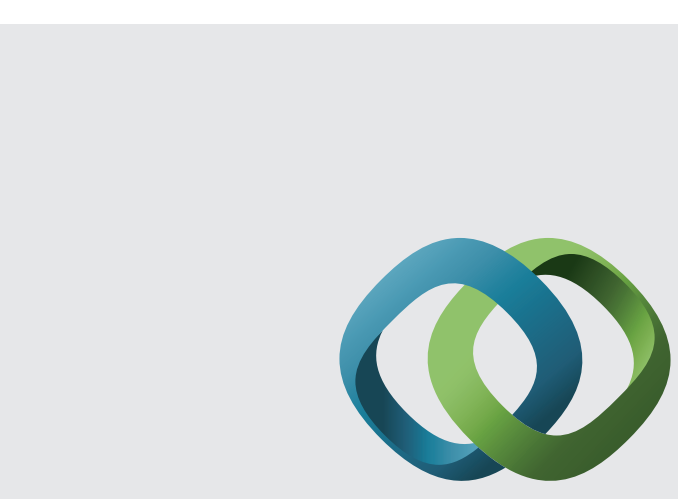

\section{Hindawi}

Submit your manuscripts at

http://www.hindawi.com
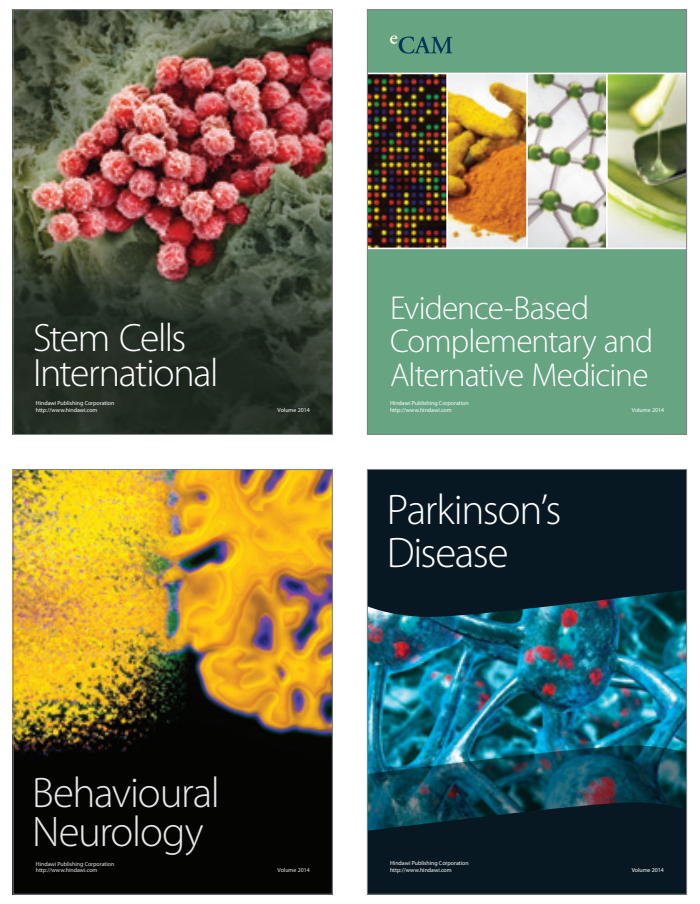
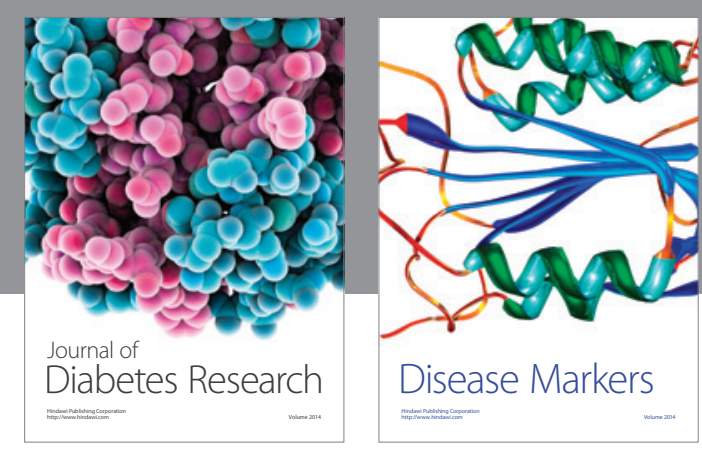

Disease Markers
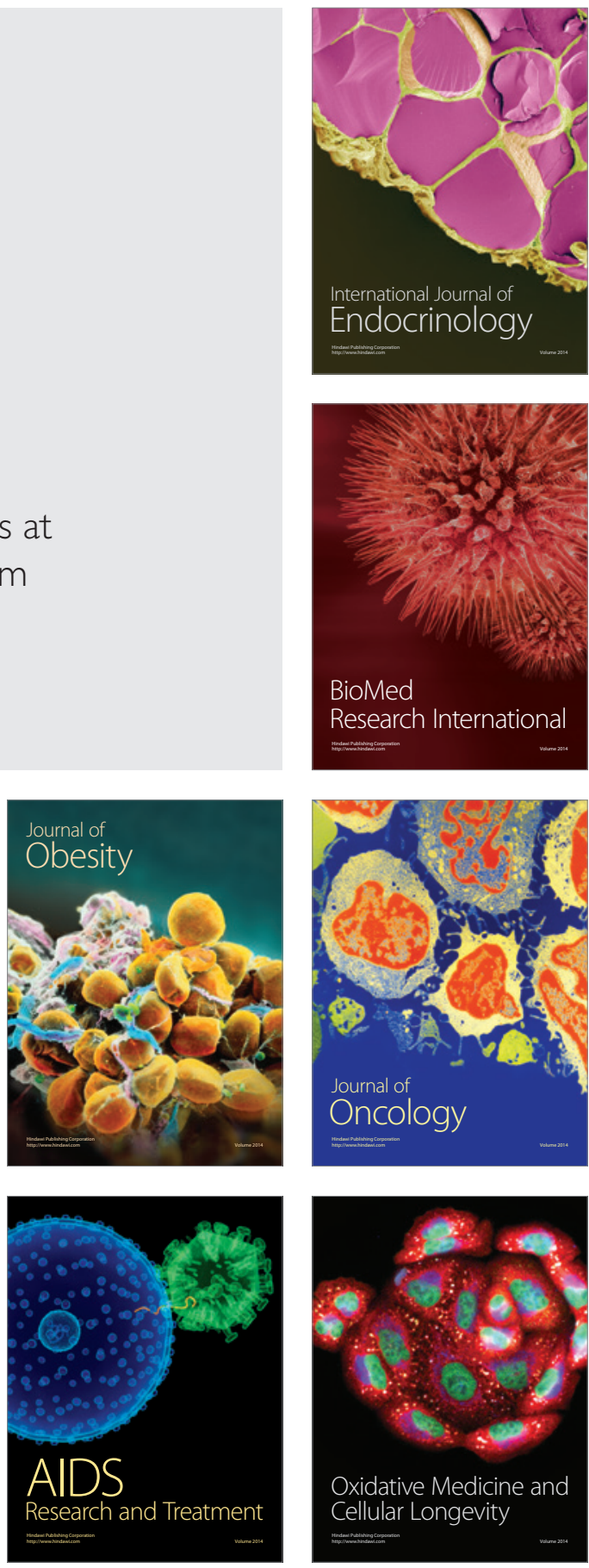